\title{
Tracking the Path of Communities of Inquiry in TEFL: A Literature Review
}

\author{
Siguiendo la ruta de comunidades de indagación \\ en la enseñanza de inglés*
}

Darlene González Miy darlene_glez@hotmail.com

Luz Edith Herrera Díaz ehd63@hotmail.com Universidad Veracruzana, Veracruz, Mexico

The community of inquiry is a techno-pedagogical framework that has gathered significant attention in online education research. It has been implemented in diverse disciplines, (foreign) language learning being one of particular interest for the authors of this paper. Due to the dynamics proposed by the framework, it appears as a practical and relevant option to generate a successful learning experience for English as a Second or Foreign Language learners. Therefore, this article provides a brief description of the model, its theoretical foundation, its applications and potential uses in the area of language learning in online environments.

Key words: Cognitive presences, online learning communities, social presences, teaching presences.

La comunidad de indagación es un modelo tecno-pedagógico que ha llamadola atención en la investigación relativa a la educación a distancia y el e-learning. Se ha implementado en diversas disciplinas, siendo el aprendizaje de lenguas una de particular interés para las autoras del presentedocumento. Debido a las dinámicas que propone este modelo, se presenta como una opción práctica y relevante para generar una experiencia de aprendizaje exitosa entre los estudiantes de inglés como segunda lengua o

* Received: November 28, 2014. Accepted: January 29, 2015.

How to cite this article (APA $6^{\text {th }}$ ed.):

González Miy, D., \& Herrera Díaz, L. E. (2015). Tracking the path of communities of inquiry in TEFL: A literature review. HOW, 22(1), 80-94.

This article is licensed under a Creative Commons Attribution-NonCommercial-NoDerivatives 4.0 International License. License Deed can be consulted at http://creativecommons.org/licenses/by-nc-nd/4.0/. 
como lengua extranjera. Por esta razón, el presente artículo ofrece una breve descripción del modelo, sus fundamentos teóricos, implementaciones y potenciales usos en el área de aprendizaje de idiomas en ambientes en línea.

Palabras clave: comunidad de aprendizaje en línea,presencia cognitiva, presencia docente, presencia social.

\section{Introduction}

Approaches and methods to language learning have significantly changed over time. From rigorous grammar dominance and translation methods, to more naturalistic, communicative or computer assisted ones, each has contributed to its linguistic purpose of language acquisition. Yet, all these approaches have something in common: their implementation is attained to the classroom, in a physical space where students and teachers meet face to face, often called the "traditional way" of learning. On the other hand, online education has made the teaching-learning process become a "flexible way," in an evidently different environment. Students and teachers are separated chronologically and geographically, but can be connected, more than ever before by means of technology. This paper explains the evolution of an approach for online education by means of a techno-pedagogical model and its application to language learning: the community of inquiry (CoI) framework. It is necessary to understand how the latter conceives learning by combining technological, human and pedagogical resources. This review of the CoI framework aims to explain its foundation, applications, and research derived from its implementations, so that it may be a useful reference for those interested in online educational models and language learning.

\section{The Revision Process}

In this section, we succinctly explain how the researchers have compiled the information, here presented, through the search in databases such as ProQuest, Web of Science, ERIC, Science Direct, Scopus, and Google Scholar. The research articles that underpin this literature review, related to the foundations, empirical studies, and implementations of the CoI framework, are the result of a selection process which started by looking for research articles related to the concepts: CoI and language learning, CoI and EFL/ESL (English as a foreign/second language), cognitive, social, teaching presences, and English teachinglearning. In order to be considered, the sources must have been published during the years 2000-2014.

From this first exploration, 52 articles, one special issue, and four books were located; one of the books was exclusively related to the CoI framework, while the other three were 
about e-learning in general; however, access was restricted to the latter ones. Additionally, several articles were retrieved from the CoI authors' website (https://coi.athabascau.ca/). The next step consisted of filtering the articles concerning the areas of education, computers, internet, and foreign language teaching-learning. Finally, only articles related to implementations in the teaching of EFL/ESL milieu were chosen, omitting those about review, reflection, and critique, as well as the ones with restricted access, which significantly reduced the number.

\section{The Community of Inquiry Framework}

Garrison, Anderson, and Archer (1999) based the CoI framework on the practical inquiry model suggested by Dewey (1938), which consists of a cycle for reflective activity that starts with a stage of pre-reflection incited by presenting a problem. Then, it continues through reflection and concludes with a satisfactory resolution or post-reflection. As shown in Figure 1 , the cognitive process begins in the lower left quarter (triggering event), and moves upward (exploration); then, it descends towards the right half (integration) to reach resolution. Passing through all four stages would lead to developing the corresponding thinking stages: action, perception, deliberation, and conception, hence, significant learning.

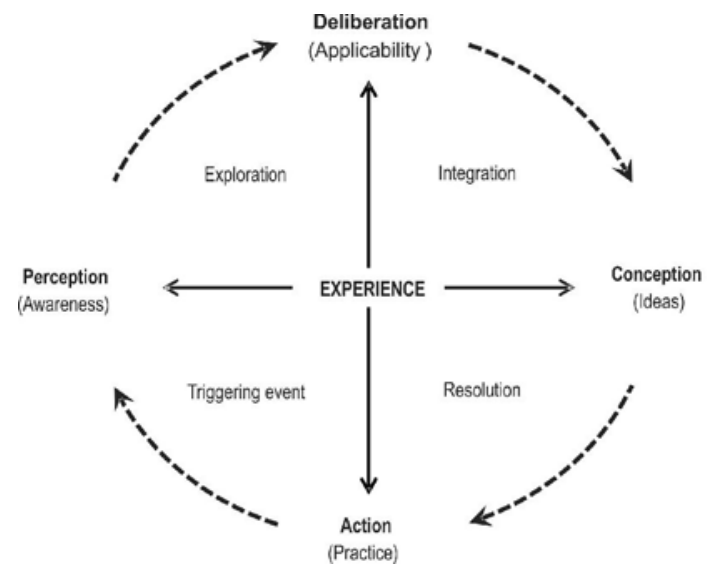

Figure 1. Practical Inquiry Model (Garrison et al., 1999)

In the early 2000, the CoI was extended to online education by a group of Canadian researchers (Garrison et al., 1999) as a result of the analysis of interactions in computer-mediated communication, especially at online discussions. Because of its designation, community and inquiry are two important words to understand. The former refers 
to a group of individuals with common expectations and interests, while the latter resembles the steps of the scientific method as a way to develop critical thinking, as conceptualized by Dewey (1938).

The CoI particularly exists within an online learning community, a group of people in an educational project of collaborative, open, participatory, and flexible learning (Gairín Sallán, 2006). It is a type of community derived from the shift of paradigm in education, which moved from knowledge transmission to its construction, from a teacher-centered approach to a student-centered one, and from passive learning to a participatory one (Harrasim, 2006). In this context, virtual learning communities comprise a participative network that stimulates communication, contribution of ideas, and socialization of experiences that lead to personal and collective identity, and as a result, builds knowledge.

On the other hand, inquiry is understood as a critical thinking and problem-solving process based on the scientific method, which leads to resolution and growth of personal and collective knowledge (Garrison, 2013). Then, inquiry implies a deep and intellectual reflection that develops, as it moves forward, into the search of possible solutions. Therefore, a community of inquiry is an online learning community that shares communication, collaboration, and critical discourse aimed at constructing meaning (Garrison, 2013). It refers to a group of people, with shared learning goals, that assumes that socialization of knowledge represents benefits for the group as it develops further learning and in a more effective way.

At the same time, the $\mathrm{CoI}$ is founded on social learning and social constructivism, collaborative learning and instructional design, and distance education (Tolu \& Evans, 2013). Its constructivist feature shares Vygotsky's vision regarding the function of language and discourse as a way to construct meaning (Wells, 2000). From the point of view of the cognition theory, individuality and collective elements do not reduce each other. Then, the focus of a $\mathrm{CoI}$ is on "the individual constructing meaning collaboratively confirming understanding through critical thinking and discourse" (Garrison, 2013, p. 5). Furthermore, Kennedy and Kennedy (2013) sustain that the CoI represents the practice of a dialogic pedagogy in an online environment. In sum, the CoI framework supports itself on social constructivism, collaborative learning, and distance education.

As mentioned before, the CoI model is based on and aimed at acquiring knowledge by constructing, collaborating, and virtuallystudying; therefore, it proposes the existence of three elements that overlap and generate a meaningful learning experience. Such elements are known as teaching, social, and cognitive presences (Garrisonet al., 1999). Figure 2 shows how each presence articulates and overlaps, creating secondary elements in the model: climate, discourse, and content; hence, altogether provide the conditions for an effective, pertinent, and relevant learning experience. 


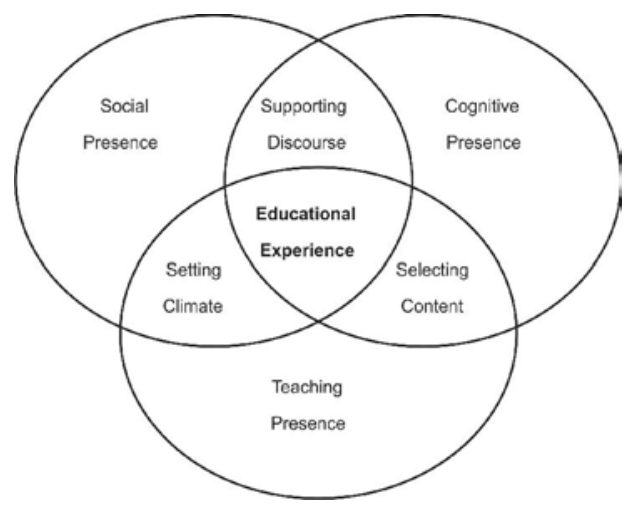

Figure 2. The Community of Inquiry Framework (Garrison et al., 1999)

Each presence has specific functions that enhance the learning experience. Namely, the social presence deals with "the ability of participants to identify with the community, communicate purposefully in a trusting environment and develop inter-personal relationships by way of projecting their individual personalities" (Akyol, 2013, p. 44). In other words, it refers to how participants establish a trustworthy atmosphere, demonstrating affective signals such as the use of names, humor, and greetings. This sense of belonging to a community emphasizes communication and creates group connections, as shown in Figure 3.

The cognitive presence relates to "the extent to which participants in any particular configuration of a community of inquiry are able to construct meaning through sustained

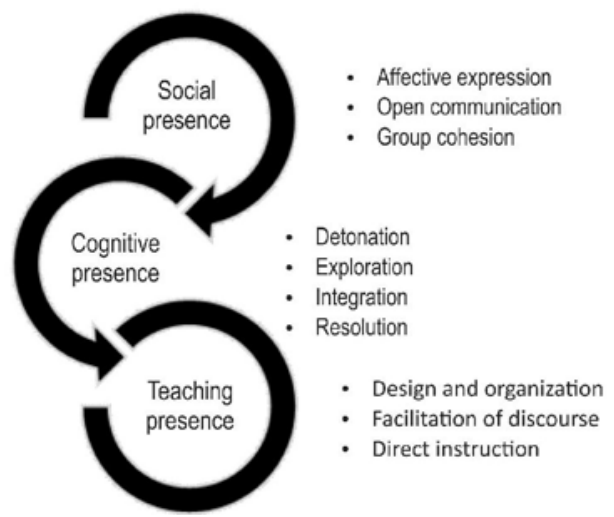

Figure 3. Elements of Social, Cognitive, and Teaching Presence (Garrison et al., 1999) 
communication" (Garrison et al., 1999, p. 89), and it is generated through the inquiry process of four stages (see Figure 3), as explained below:

1. Detonation (triggering event): provokes interest and leads to discussion around a topic, usually presented in the form of a problem.

2. Exploration: generates ideas, opinions, exchange, and discussion, it attempts to find a solution.

3. Integration: promotes meaningful learning by integrating reflection and discourse, and previous ideas start to make sense.

4. Resolution: reaffirms learning by applying acquired knowledge.

Completing all four phases is crucial to achieve higher order thinking skills; however, careful design is necessary to guarantee all stages. As Arbaugh, Bangert, and Cleveland-Innes (2010) have demonstrated, learners often achieve the first two with relative ease, but struggle to reach the last two. In sum, social presence is the one that characterizes the inquiry learning process in this framework.

The last component of this triad is the teaching presence, defined by Anderson, Rourke, Garrison, and Archer (2001) as "the designing and managing [of] learning sequences, providing subject matter expertise, and facilitating active learning" (p. 3). Along the same lines, Aykol (2013) describes this presence as "the design, facilitation and direction of cognitive and social processes with the purpose of realizing personally meaningful and educationally worthwhile learning outcomes" (p. 44).

Thus, the teaching presence bridges cognitive and social elements by implementing activities that promote independent study and build community by deeply exploring content and offering diverse forms of formative assessment to individual and collective needs. The teacher carries out three main functions as indicated in Figure 3:

- Plans, structures, and establishes learning objectives, strategies, assessment, and communication etiquette.

- Promotes participation, makes comments on learners' posts, redirects discussion, and keeps interest of participants.

- Directs the community, provides feedback, and uses resources for learning according to his expertise.

As it has been demonstrated, while these presences overlap, new dimensions are created (see Figure 2). The intersection of the cognitive and the teaching presences regulates the interaction between content and learning goals. The social presence overlaps with the teaching presence allowing the development of personal relations and fraternity. Correspondingly, the joining of the social and the cognitive presences promotes critical 
discourse and continuous communication. According to Garrison et al. (1999), altogether, presences and dimensions create a successful learning experience.

\section{The Communities of Inquiry in Teaching EFL/ESL}

This section reports detailed research findings of implementations, results, limitations, and future applications of $\mathrm{CoI}$ in the teaching of EFL/ESLmilieu. ${ }^{1}$

In a mixed-method study carried out with undergraduate students of information technology at an Iranian university, taking an English for specific purposes online writing course, Asoodar, Atai, Vaezi, and Marandi (2014) confirmed the effectiveness of using blogs for educational purposes. They used the blog-buddy application to allow interaction among the students, the instructor, and the application. Additionally, Moodle, email, chat rooms, and Adobe Acrobat Meeting Pro were used. Results reported that students showed higher levels of satisfaction regarding their discussions in the virtual course because they could share their knowledge and experience with their peers. The students were also able to understand other points of view in an interactive and highly attractive format, and they perceived the flexibility of virtual classes as a positive factor, since they could log in at any time and from any place.

Asoodar et al. (2014) used the CoI framework to observe the construction of the community, and through a quantitative analysis confirmed that participants with a higher sense of community (social presence) showed better academic performance and better grades (cognitive presence). On the other hand, the qualitative analysis provided evidence of how collaboration in an online learning community helped students to learn by means of co-construction of knowledge (social-cognitive presences) as they participated in online activities. Moreover, these authors proposed an assessment model based on constructivism and social interaction theories of learning. Through this assessment model, they found out that textbooks were not updated and were based on traditional teaching methods. So, even though the virtual proposal was innovative, they state that different methods should be implemented to make English learning more effective (Atai, 2006).

Tolu's (2010) study showed that a community is built and improved by keeping synchronous communication. This mixed-method study was conducted at a metropolitan public university in southeastern US with 13 Online ESOL (English for speakers of other

1 For research on complete implementations of the CoI in other disciplines see Akyol, Garrison, and Ozden, (2009); Arbaugh (2008); Arbaugh et al. (2008); Arbaugh et al. (2010); Burguess, Slate, Rojas-LeBouef, and LaPrairie (2010); Garrison, Cleveland-Innes, and Fung (2010); Goda and Yamada (2013); Ke (2010); Kumar, Dawson, Black, Cavanaugh, and Sessums (2011); Lambert and Fisher (2013); Shea and Bidjerano (2010); Stein et al. (2007); Stodel, Thompson, and MacDonald, (2006); Vaughan and Garrison (2005). 
languages) pre-service teachers. Activities such as quizzes, exercises, reflection papers, case projects, exams, and live meetings were implemented during the course of study. These were carried out using the software Elluminate live and other tools like instant messenger, Gmail chat, and Blackboard email. Live meetings reported the manifestation of the three presences, so, the students perceived the class as more real, which was positive for learning. Moreover, live sessions promoted cognitive presence, as participants could listen to the teacher's and peers' presentations displayed throughout different technological tools (whiteboard, chat, video, and microphone) available in this software.

The social presence was mainly achieved through chat communication. This tool fostered the teacher's availability, and therefore, reported students' higher level of satisfaction. Instant communication and audio promoted social presence, as participants felt comfortable with the environment of the class. This study proved to be relevant to the ESOL area, since it proposed an innovative way to prepare language teachers by means of technology, better than by using traditional didactic materials.

Alavi and Taghizadeh (2013) implemented a quantitative exploration at Iran University of Science and Khajeh Nasir Toosi University of Technology. By applying a Persian version of the CoI survey, based on indicators of cognitive presence, to 107 undergraduate students of science and technology taking an online English language course at two virtual centers, the authors found out that the four stages proposed in the CoI model hardly existed in the online course.

At the beginning stage or triggering event, students did not feel attracted to reflection. One possible reason might have been that textbooks were not updated and courses were based on the grammar translation method, which is a very traditional approach to language learning. Moreover, there was a lack of flexibility; learners' interaction schedules in the virtual environment and course contents were fixed in advance by course administrators. Thus, this teacher-centered focus was a negative feature as opposed to the learner-centered focus presumed by online education.

Conditions such as numerous learners, limited time to cover the syllabus, and difficulty to organize collaborative projects constrained the opportunities for learners to provide supporting or contradicting ideas, or to extend a discussion. Consequently, all these circumstances did not engender the appropriate environment to establish an exploration stage.

Regarding the integration stage of the cognitive presence, the abovementioned issues did not leave room for critical discourse either from the students or from the instructor. The focus on improving grammar, reading, and vocabulary was the goal in the resolution stage; therefore, listening, speaking, and writing activities were relegated. It can be mentioned that 
something valuable about this diagnostic was obtaining data which could be useful to course designers, virtual instructors, and teachers that are incorporating language online courses.

Arnold and Ducate (2006) conducted a mixed study with two groups of foreign language teachers in methodology hybrid courses (face to face classes and online discussions) at two universities. The participants' nationalities were German, French, and Spanish, but the courses were conducted in English. Electronic discussion boards were used to foster interaction among participants from both institutions. The findings revealed that the level of social presence was higher than the level of the cognitive one. Students were pleased relating to peers in other universities and felt comfortable in a free, relaxed environment for discussions, so, they engaged in high level social activity.

Regarding cognitive presence, electronic discussions promoted learning as partners' contributions exposed different perspectives and clarification of concepts, while sharing ideas for classroom practice. Even though the results were statistically positive and students involved in deep discussion, the resolution stage was not reached. Intentionally, teachers only participated by providing a triggering event but did not take part in the discussion; thus, the teacher's assistance might be a necessary element to accomplish the integration stage. For further research, we can say that being a native or non-native speaker of English is another aspect that needs deeper investigation in order to find out its effect on the levels of cognitive and social presences.

Another interesting proposal is that by Randrianasolo (2013). Based on the theoretical foundations of the CoI, this paper presented a project to redesign a writing course at Purdue University in Indiana, USA. The course would include the use of technological tools such as Blackboard, Adobe connect, Skype, Google Hangout, and social media such as Facebook and Twitter, to develop course activities such as online discussion, peer review, and composition (social presence). The author argued that the unique characteristics of international learners, regarding their educational background, culture, and language proficiency, made this approach suitable for this course.

Even though the course would not be intended to teach the language, it might benefit international students, as they could develop language skills (cognitive presence) not only from the course but also from the interaction with instructors (teaching presence) and more proficient peers. Up to the date of publication, the study remained as a proposal and results were still unknown; however, in the near future it might offer interesting data for those involved in course design for this particular population.

Although online education offers flexibility, students often perceive online courses more demanding than traditional ones. Such is the case of the qualitative study carried out by Chen (2012) in the MA in TESOL program at the University of Southern California in Los Angeles. Chen analyzed the effectiveness of teachers' courses in terms of development, 
implementation and evaluation. The findings suggested that academic demand was identified as a strength in terms of learning, while technical issues such as platform instability (WebCT, Blackboard) and audio and video resource failure appeared as weaknesses. On the other hand, personality, organization skills, and learning styles were characteristics associated with successful students, while innovative personality, strong organization, and superior technological skills were connected to instructors. The implementation of activities and assignments that could be used to practice with consisted of effective components that encouraged students to reach the resolution stage.

The cognitive presence seemed to be developed by participating in discussions and reflection; however, participants were not very engaged in productive dialogue. The social presence was developed by participating in course discussions and interacting with other participants, thus, group cohesion was developed through collaboration. Regarding the teaching presence, instructors struggled with design and organization, due to the fact that the actual time taken for the task differed from the originally estimated time. More guidance for understanding concepts was identified as a necessity, so, facilitation seemed to be an aspect to improve, possibly through different teaching techniques. Conclusions of this study reported that the CoI framework proved practical, even though there are pedagogical considerations to improve.

In Lomicka and Lord (2007), 14 instructors participated in a quantitative study carried out at two universities in the United States. Using group journals as the learning product, three experimental groups were analyzed in terms of the social presence. The first group worked on traditional journals and then submitted them for grading, and no feedback was received. The second one wrote their journals, exchanged them, and received peer feedback. And the third group published the journals in an electronic discussion board; every participant had access to it, so that they were able to provide feedback. Intentionally, the instructor did not participate in any of the groups. Results showed that the affective component was more evident in the group that worked the journals electronically; some evidences were expressing feelings, self-constructive comments and compliments, showing vulnerability, giving advice and opinions, asking questions, agreeing, using names and salutations. Although interaction levels were high at the beginning of the course, they decreased throughout the semester; hence, group cohesion was the aspect with the lowest statistical representation. In the end, this research proved that different dynamics and forms of interactions had an effect on the degree of the social presence.

A study closely associated with the development of language skills was carried out by Olesova, Richardson, Weasenforth, and Meloni (2011). It was applied in the context of a content-based ESL class in the Unites States and a content-based EFL class in Russia. This investigation included 39 students and two instructors, a native speaker, and a non-native 
speaker of English, who developed a five-week online reading project supported by a wiki and Vocaroo. Both instructors provided written feedback, and the Russian instructor provided audio feedback (teaching presence). After statistical treatment, the study reported a slightly higher level of satisfaction in receiving audio feedback, as this was personal, interesting, and motivating, which made the students feel part of the course. Being able to listen to the non-native instructor's voice (inflection and pronunciation) helped to retain more information than in written form (cognitive presence). On the other hand, written feedback was considered more effective than audio feedback by EFL students, as they could visualize and read the comments for better comprehension. An interesting result was that EFL students reported a higher level of comprehension of the instructor's voice than ESL students, which raises the question about the effect of the learning context. Olesova et al. suggested interesting future research opportunities related to examining the differences in students' perceptions of native-speaker-voice audio feedback, and the correlation between EFL/ESL students' language skills and audio feedback in terms of learning outcomes.

Yamada, Goda, Matsukawa, Hata, and Yasunami (2014) investigated the correlation between psychological factors (perceptions) and learning behaviors (utterances) during the implementation of the CoI framework in an EFL class through computer-supported collaborative learning (CSCL). The study consisted of two experiments; the first one aimed at establishing social presence by means of online discussion using reading and listening activities from the Voice of America website. A topic was selected, discussed for a week, and followed by the instructor's intervention.

Results suggested that the perceived cognitive presence reduced the number of utterances in the social presence. The second experiment consisted of a forty-minute online discussion on a given topic. The CSCL, consisting of a chatbot and CD-map, ${ }^{2}$ was used in this experiment. Students were divided into four small groups; one had both tools, another one had only a chatbot but not the map, one more had the map but not the chatbot, and the last one had none of the tools. Data obtained demonstrated that these tools had a positive effect on active discussion. Yamada et al. (2014) suggested that future research should look at the correlation between functional tools and language learning and performance, as well as the continuity of the CoI framework out of class.

2 The chatbot is a window added to a chat that asks participants to answer questions regarding a discussion topic, using the Socratic Method, before a group discussion. The "CD-map" is a tool, within the chat, that creates a concept map while chatting with other participants, who post their ideas and opinions, register postings as "favorites", use emoticons, and create relationships. 


\section{Conclusion}

The sources reviewed in this article have provided a wide perspective around the CoI framework and its application in the English teaching-learning field. The research studies consulted have qualitatively and/or quantitatively demonstrated the existence of the social, cognitive, and teaching presences, constituting the CoI framework suggested by Garrison et al. (1999), in diverse settings where it has been implemented.

In a similar vein, the theoretical foundations of this techno-pedagogical model may be useful to apply the CoI as a framework to design educational experiences for higher levels of language learning. Thus, designing effective instructional activities and resources, offering enhanced online teaching strategies and encouraging engagement of participants in interaction, that is, the teaching presence, could result in the promotion of the other two presences, the social and the cognitive. In some studies, it has been noticed that the cognitive presence promotes learning in electronic discussions when participants' contributions show their different perspectives while sharing ideas (social presence).

Some of these studies have explained how a CoI works and how it is established; however, few of them focus on language teaching/learning outcomes. Besides, most of the abovementioned studies have been implemented in North American education institutions, therefore, it should be an opportunity to extend this kind of research in contexts with different cultural, educational, and linguistic backgrounds, that is, in diverse contexts. It is suggested that further research include investigating the effect of CoI components in the development of language skills, which could be useful in disseminating and taking advantage of the CoI framework in the teaching of EFL/ESL milieu.

\section{References}

Akyol, Z. (2013). Metacognitive development within the community of inquiry. In D. R. Garrison \& Z. Akyol (Eds.), Educational communities of inquiry: Theoretical framework, research and practice (pp. 30-44). Hershey, PA: Information Science. http://dx.doi.org/10.4018/978-1-4666-2110-7. ch003.

Akyol, Z., Garrison, D. R., \& Ozden, M. Y. (2009). Online and blended communities of inquiry: Exploring the developmental and perceptional differences. The International Review of Research in Open and Distance Learning, 10(6), 65-83. Retrieved from http://www.irrodl.org/ index.php/irrodl/article/view/765/1436.

Alavi, S. M., \& Taghizadeh, M. (2013). Cognitive presence in a virtual learning community: An EFL Case. International Journal of E-learning \& Distance Education, 27(1). Retrieved from http://www.ijede.ca/index.php/jde/article/view/818.

Anderson, T., Rourke, L., Garrison, D. R., \& Archer, W. (2001). Assessing teaching presence in a computer conference environment. Journal of Asynchronous learning Networks, 5(2), 1-17. 
Arbaugh, J. B. (2008). Does the community of inquiry framework predict outcomes in online MBA courses? The International Review of Research in Open and Distributed Learning, 9(2). Retrieved from http://goo.gl/tDN3lc.

Arbaugh, J. B., Bangert, A., \& Cleveland-Innes, M. (2010). Subject matter effects and the community of inquiry (CoI) framework: An exploratory study. The Internet and Higher Education, 13 (1-2), 37-44. http://dx.doi.org/10.1016/j.iheduc.2009.10.006.

Arbaugh, J. B., Cleveland-Innes, M., Diaz, S. R., Garrison, D. R., Ice, P., Richardson, J. C., \& Swan, K. P. (2008). Developing a community of inquiry instrument: Testing a measure of the community of inquiry framework using a multi-institutional sample. The Internet and Higher Education, 11(3-4), 133-136. http://dx.doi.org/10.1016/j.iheduc.2008.06.003.

Arnold, N., \& Ducate, L. (2006). Future foreign language teachers' social and cognitive collaboration in an online environment. Language Learning \& Technology, 10(1), 42-66. Retrieved from http://llt.msu.edu/vol10num1/arnoldducate/default.html.

Asoodar, M., Atai, M. R., Vaezi, S., \& Marandi, S. S. (2014). Examining effectiveness of communities of practice in online English for academic purposes (EAP) assessment in virtual classes. Computers \& Education., 70, 291-300. http://dx.doi.org/10.1016/j.compedu. 2013.08.016.

Atai, M. R. (2006). EAP teacher education: Searching for an effective model integrating content and language teachers' schemes. Retreived from: http://www.paaljapan.org/resources/ proceedings/PAAL11/pdfs/03.pdf.

Burguess, M. L., Slate, J. R., Rojas-LeBouef, A., \& LaPrairie, K. (2010). Teaching and learning in Second Life: Using the community of inquiry (CoI) model to support online instruction with graduate students in instructional technology. The Internet and Higher Education, 13(1-2), 84-88. http://dx.doi.org/10.1016/j.iheduc.2009.12.003.

Chen, S. T. (2012). Perceptions of online TESOL teacher education: Strengths, weaknesses, characteristics, and effective components (Doctoral dissertation). University of Southern California, USA.

Dewey, J. (1938). Logic: The theory of inquiry. New York, NY: Holt, Rinehart and Winston.

Gairín Sallán, J. (2006). Las comunidades virtuales de aprendizaje [Virtual communities of learning]. Educar, 37, 41-64.

Garrison, D. R. (2013). Theoretical foundations and epistemological insights of the community of inquiry. In Z. Akyol \& D. R. Garrison (Eds.), Educational communities of inquiry: Theoretical framework, research and practice (pp. 1-11). Hershey, PA: Information Science Reference. http://dx.doi.org/10.4018/978-1-4666-2110-7.ch001.

Garrison, D. R., Anderson, T., \& Archer, W. (1999). Critical inquiry in a text-based environment: Computer conferencing in higher education. The Internet and Higher Education, 2(2-3), 87-105. http://dx.doi.org/10.1016/S1096-7516 (00)00016-6.

Garrison, D. R., Cleveland-Innes, M., \& Fung, T. S. (2010). Exploring causal relationships among teaching, cognitive and social presence: Student perceptions of the community of inquiry framework. The Internet and Higher Education, 13(1-2), 31-36. http://dx.doi.org/10.1016/ j.iheduc.2009.10.002. 
Goda, Y., \& Yamada, M. (2013). Application of CoI to design CSCL for EFL online asynchronous discussion. In Z. Akyol \& D.R. Garrison (Eds.), Educational communities of inquiry: Theoretical framework, research and practice (295-316). Hershey, PA: Information Science Reference. http://dx.doi.org/10.4018/978-1-4666-2110-7.ch014.

Harrasim, L. (2006, March). Online collaborative learning (OCL): The next generation for elearning. Public presentation made in Sao Paulo, Brazil.

Ke, F. (2010). Examining online teaching, cognitive, and social presence for adult students. Computers \& Education, 55(2), 808-820. http://dx.doi.org/10.1016/j.compedu.2010.03.013.

Kennedy, D., \& Kennedy, N. S. (2013). Community of philosophical inquiry online and off: Retrospectus and prospectus. In Z. Akyol \& D. R. Garrison (Eds.), Educational communities of inquiry: Theoretical framework, research and practice (pp. 12-29). Hershey, PA: Information Science Reference. http://dx.doi.org/10.4018/978-1-4666-2110-7.ch002.

Kumar, S., Dawson, K., Black, E., Cavanaugh, C., \& Sessums, C. (2011). Applying the community of inquiry framework to an online professional practice doctoral program. The International Review of Research in Open and Distributed Learning, 12(6), 126-142.

Lambert, J. L., \& Fisher, J. L. (2013). Community of inquiry framework: Establishing community in an online course. Journal of Interactive Online Learning, 12(1), 1-16.

Lomicka, L., \& Lord, G. (2007). Social presence in virtual communities of foreign language (FL) teachers. System, 35(2), 208-228. http://dx.doi.org/10.1016/j.system.2006.11.002.

Olesova, L., Richardson, J., Weasenforth, D., \& Meloni, C. (2011). Using asynchronous instructional audio feedback in online environments: A mixed methods study. MERLOT Journal of Online Learning and Teaching, 7(1). Retrieved from http://jolt.merlot.org/vol7no1/ olesova_0311.htm.

Randrianasolo, S. (2013). Moving online: Using the community of inquiry framework to redesign English composition for international students (doctoral dissertation). Purdue University, USA.

Shea, P., \& Bidjerano, T. (2010). Learning presence: Towards a theory of self-efficacy, self-regulation, and the development of a communities of inquiry in online and blended learning environments. Computers and Education, 55(4), 1721-1731. http://dx.doi.org/ 10.1016/j.compedu.2010.07.017.

Stein, D. S., Wanstreet, C. E., Glazer, H. R., Engle, C. L., Harris, R. A., Johnston, S. M., .. Trinko, L. A. (2007). Creating shared understanding through chats in a community of inquiry. The Internet and Higher Education, 10(2), 103-115. http:/ /dx.doi.org/10.1016/j.iheduc.2007.02.002.

Stodel, E. J., Thompson, T. L., \& MacDonald, C. J. (2006). Learners' perspectives on what is missing from online learning: Interpretations through the community of inquiry framework. The International Review of Research in Open and Distributed Learning, 7(3). Retrieved from http://www.irrodl.org/index.php/irrodl/article/view/325/743.

Tolu, A. T. (2010). An exploration of synchronous communication in an online pre-service ESOL course: Community of inquiry perspective (doctoral dissertation). University of South Florida, USA.

Tolu, A. T., \& Evans, L. S. (2013). From distance education to communities of inquiry: A review of historical developments. In Z. Akyol \& D. R. Garrison (Eds.), Educational communities of inquiry 
theoretical framework, research and practice (pp. 45-65). Hershey, PA: Information Science Reference. http://dx.doi.org/10.4018/978-1-4666-2110-7.ch004.

Vaughan, N., \& Garrison, D. R. (2005). Creating cognitive presence in a blended faculty development community. Internet and Higher Education, 8(1), 1-12. http://dx.doi.org/ 10.1016/j.iheduc.2004.11.001.

Wells, G. (2000). Dialogic inquiry in education: Building on the legacy of Vygotsky. In C. D. Lee \& P. Smagorinsky (Eds.), Vygotskian perspectives on literacy research: Constructing meaning through collaborative inquiry (pp. 51-55). New York, NY: Cambridge University Press.

Yamada, M., Goda, Y., Matsukawa, H., Hata, K., \& Yasunami, S. (2014). What psychological factors enhance a language learning community? Toward effective CSCL design for language learning based on a CoI framework. In E. Popescu, R. W. H. Lau, K. Leung, \& M. Laanpere (Eds.), Advances in web-based learning - ICWL 2014 (pp. 43-55). Switzerland: Springer. http://dx.doi.org/10.1007/978-3-319-09635-3_5.

\section{The Authors}

Darlene González Miy is an English e-tutor and teacher. She holds an MA in TEFL from Universidad de Jaén (Spain). She is a doctoral student (Educational Systems and Environments) at Universidad Veracruzana (Mexico).

Luz Edith Herrera Díaz is a professor-researcher at the Language Center in Universidad Veracruzana (Mexico). She is currently a teacher and the coordinator of the MA TEFL program in Veracruz. She holds a PhD in language studies (Kent University, UK). 